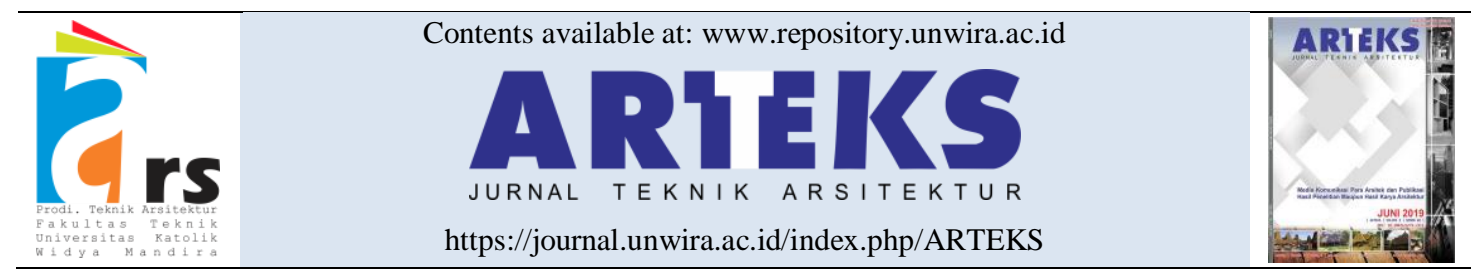

Research paper

doi: http://doi.org/10.30822/arteks.v4i1.81

\title{
Hilangnya karakter pedestrian shopping street Jalan Tunjungan akibat transformasi Surabaya sebagai Kota Metropolitan
}

\section{Anneke Clauvinia Patriajaya, Yohanes Karyadi Kusliansjah*}

Program Studi Magister Arsitektur, Fakultas Teknik, Universitas Katolik Parahyangan

Jl. Merdeka, No. 30, Bandung, Indonesia

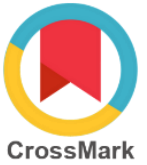

\begin{tabular}{l}
\hline ARTICLE INFO \\
\hline Article history: \\
Received June 25, 2019 \\
Received in revised form July 18, 2019 \\
Accepted September 23, 2019 \\
Available online December 16, 2019
\end{tabular}

\section{Keywords: \\ Jalan Tunjungan \\ Loss of character \\ Pedestrian shopping street \\ Surabaya Metropolitan City \\ Transformation}

*Corresponding author: Yohanes Karyadi Kusliansjah

Program Studi Magister Arsitektur, Fakultas Teknik, Universitas Katolik Parahyangan, Indonesia

Email:karyadi@unpar.ac.id

\author{
ABSTRACT \\ The loss of pedestrian shopping street characters in Jalan \\ Tunjungan due to the transformation of Surabaya as a \\ Metropolitan City
}

In general, there are centers of commercial activity in a city. Through the patterns of development of commercial activities, a pedestrian shopping street typology which prioritizes pedestrians in its pattern and activity system was born. Jalan Tunjungan Surabaya represents this typology well because it was developed to be a pedestrian-based shopping area in Gemeente government era. Along with the development of Surabaya, the uniqueness of the urban artefact of Tunjungan area is transformed and being dominated by multi-storey buildings and Jalan Tunjungan became a city axis. The uniqueness of Jalan Tunjungan which was able to attract tourists is endangered due to the demands of Surabaya's economic development. Through a synchronic-diachronic approach with qualitative-descriptive methods, this study aims to identify patterns, types, and systems that create the physical-spatial characteristics of pedestrian shopping street in Jalan Tunjungan that has remained adapted and lost due to the transformation of Surabaya as a metropolitan city. Through comparative analysis, the findings conclude that the only thing remains is the linearity pattern of the building structure, while the type of road is adapted into oneway avenue with planned lane division and the addition of on-site parking system. Building types is adapted into commercial buildings. The characteristics of the arcades in some buildings are lost, the transportation system removes the passenger stop, the bridge is no longer being used, and the pedestrian pattern is disrupted due to the pattern of traffic. Jalan Tunjungan, which used to prioritize the experience of shopping by walking, has been degraded to a shopping street area.

\section{Pendahuluan}

Kegiatan perekonomian merupakan hal fundamental yang menjadi determinan perkembangan kota (Jayadinata 1986). Pada kota umumnya terdapat kawasan yang tumbuh dan dikembangkan menjadi sentral aktivitas komersial. Pertumbuhan kota dimulai dari pusat kota lama sebagai bekas kawasan pusat perdagangan dan perekonomian kota (Lake, Mberu, and Diaz 2019).

Berdasarkan polanya, perkembangan aktivitas komersial dapat dikategorikan menjadi 3 (tiga) kelompok (Hartshorn 1992), yaitu:

i. $\quad$ Centers, memusat di suatu area;

ii. Ribbon, tersebar di sepanjang jaringan jalan; 
iii. Specialized area, area dengan komoditas serupa atau yang saling berhubungan.

\section{Pedestrian shopping street}

Tipologi komersial yang lahir akibat pola perkembangan aktivitas komersial ribbon adalah pedestrian shopping street (Laskara 2018).

Karakteristik fisik-spasial pedestrian shopping street dapat dilihat (Alexander et al. 1977) dari:

i. Deretan bangunan pertokoan beserta dengan fasadnya.

ii. Akses jalan di antara sisi kiri dan kanan deretan bangunan pertokoan.

iii. Sistem perparkiran khusus yang terletak langsung di depan bangunan.

iv. Penyediaan sistem transportasi.

v. Sistem sirkulasi service yang jelas untuk bangunan pertokoan.

vi. Pengalaman berjalan yang baik (promenade) dengan memperhatikan dimensi jalan, material, dan aspek pendukung lainnya.

Yang membedakan antara pedestrian shopping street dengan shopping street adalah tipologi ini mengutamakan pejalan kaki dalam pola dan sistem belanjanya (Hendrawan and Dwisusanto 2017).

Jalan Tunjungan dengan karakteristik pedestrian shopping street

Berada di pesisir Utara Pulau Jawa, Surabaya menjadi kota dengan perkembangan perekonomian yang pesat (Hartono and Handinoto 2007). Perkembangan aktivitas komersial di Surabaya membentuk pola ribbon. Pola inilah melahirkan Jalan Tunjungan dengan karakteristik fisik-spasial pedestrian shopping street. Jalan Tunjungan menarik untuk dikaji karena letaknya di pusat Kota Surabaya dan dikembangkan sebagai kawasan elit perbelanjaan yang mengutamakan pengalaman berjalan kaki tahun 1906-1940, yaitu periode Belanda menjadikan Surabaya sebagai kotamadya atau lebih dikenal dengan periode pemerintahan Gemeente (Basundoro 2016). Kawasan ini tetap menjadi jantung perekonomian Kota Surabaya dengan urban artefak pedestrian shopping street. Oleh karena itu, kawasan Tunjungan merupakan bukti dinamika perkembangan perekonomian Surabaya (Poerbantanoe 1999).

Pembangunan Kota Surabaya yang berdampak pada Jalan Tunjungan dapat dilihat dalam 5 (lima) periode (Handinoto 1996); (Mutfianti 2013), yaitu: i. 1870-1905, kelahiran Jalan Tunjungan.

ii. 1906-1940, periode keemasan Jalan Tunjungan sebagai pedestrian shopping street pemerintahan Gemeente.

i. 1941-1970, pra-pasca kemerdekaan dimana tidak ada transformasi pada Jalan Tunjungan.

ii. 1971-1990, Jalan Tunjungan mengalami beberapa perubahan akibat perkembangan perekonomian yang pesat.

iii. $>1990$, fenomena blok vertikal mixed use.

Jalan Tunjungan di era Surabaya Kota Metropolitan

Karena keunikannya, Jalan Tunjungan tumbuh sebagai identitas Surabaya dan menjadi tujuan wisata hingga akhir abad ke-20. Jalan Tunjungan kini berada di kawasan yang didominasi bangunan mixed use bertingkat (Mutfianti 2013). Fenomena ini mengubah Jalan Tunjungan dengan karakteristik pedestrian shopping street menjadi poros kota. Keunikan urban artefak pedestrian yang menjadi daya tarik kawasan ini ikut mengalami transformasi, bahkan terancam punah akibat tekanan dan tuntutan perkembangan perekonomian Kota Surabaya (Perdana 2017). Pemerintah Kota Surabaya berusaha mengembalikan kembali masa keemasan Jalan Tunjungan yang mengedepankan pengalaman berjalan kaki (Effendi 2015).

Kajian ini bertujuan untuk mengetahui pola, tipe, dan sistem yang membentuk karakteristik fisik-spasial pedestrian shopping street Jalan Tunjungan yang bertahan dari masa pemerintahan Gemeente, mengalami adaptasi, dan hilang di era Surabaya Kota Metropolitan. Diharapkan kajian ini bermanfaat dalam menambah wawasan dan pengetahuan mengenai karakteristik fisik-spasial Jalan Tunjungan dan temuan dari studi ini dapat menjadi referensi pertimbangan dalam usaha pemerintah Surabaya mengembalikan masa keemasan Jalan Tunjungan.

\section{Metode penelitian}

Kajian ini bersifat studi karakteristik fisik-spasial pedestrian shopping street Jalan Tunjungan dari awal kelahirannya hingga sekarang. Pendekatan sinkronik-diakronik dengan metode kualitatifdeskriptif dipakai dalam membedah kasus studi. Penelitian sinkronik berarti mendeskripsikan kasus studi secara gamblang pada periode tertentu (Salura 2010). Sedangkan dalam penelitian 
diakronik, kasus studi dikaji dari awal kelahirannya hingga kini (Chaer 2003).

Penelitian dimulai dengan menjabarkan elemen urban form (Kostof, Castillo, and Tobias 1999), yaitu: access/street, edge, subdivision, open space, dan building. Data-data elemen urban form didapat dari:

i. Data primer didapat dari pengamatan langsung ke kasus studi dengan melakukan perekaman berupa foto, sketsa, dan pengukuran. Selain itu, dilakukan wawancara pada beberapa narasumber yang melakukan penelitian sebelumnya dan mengetahui perkembangan kasus studi.

ii. Data sekunder didapat dari penelitian terdahulu, studi literatur, dan dokumen kesejarahan yang terkait (foto, peta, dan lainlain).
Data urban form dicari dalam 5 (lima) periode waktu pembangunan dengan meniadakan periode 1941-1970 dan menambah periode waktu >2017 untuk melihat keadaanya sekarang.

Analisa data dimulai dengan mencari pola, tipe, dan sistem (Habraken 2000) dari 5 (lima) elemen urban form sehingga dapat dikenali karakteristik pedestrian shopping street pada lokasi studi. Analisa dilanjutkan dengan mengkomparasi pola, tipe, dan sistem yang terjadi pada tiap periode dan hasilnya disajikan dalam bentuk diagram, sehingga dapat ditemukan karakteristik fisik-spasial pedestrian shopping street Jalan Tunjungan yang bertahan, mengalami adaptasi, dan hilang di era Surabaya Kota Metropolitan.

Garis besar tahapan studi dapat dilihat pada gambar 1.

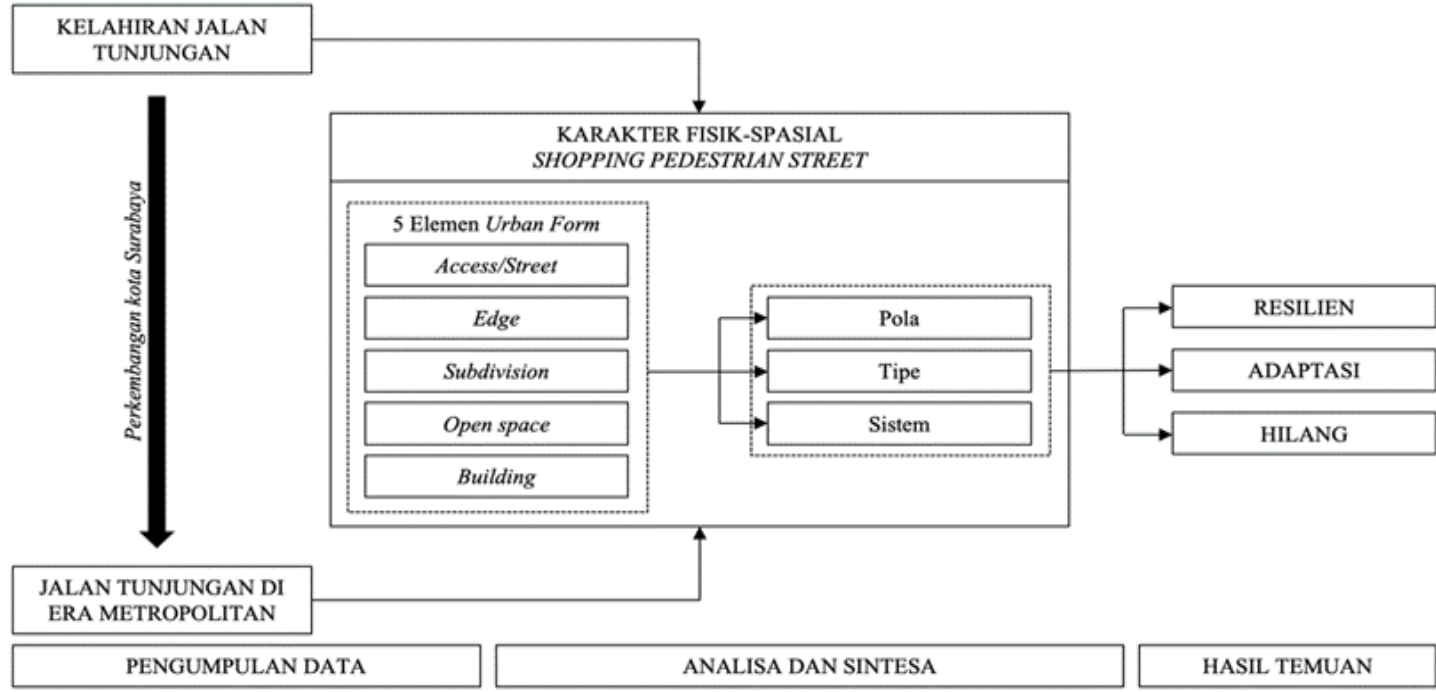

Gambar 1. Kerangka berpikir dan tahapan studi

\section{Temuan dan pembahasan}

Access/street
Linieritas pola ruang Jalan Tunjungan bertahan dari awal kelahirannya hingga kini. Perkembangannya dapat dilihat dari tabel 1 di bawah ini:

Tabel 1. Perkembangan pola akses di Jalan Tunjungan

\begin{tabular}{|c|c|c|c|c|c|}
\hline & $1870-1905$ & 1906-1940 & 1971-1990 & $>1990$ & $>2017$ \\
\hline Peta & & & 48 & & \\
\hline
\end{tabular}




\begin{tabular}{lllll}
\hline & $1870-1905$ & $1906-1940$ & 1990 & $>17$ \\
\hline & & & \\
\hline
\end{tabular}

Berdasarkan tabel 2 (lihat tabel 2), terlihat bahwa tipe jalan di Jalan Tunjungan pada awal kelahirannya adalah road, dimana tidak ada pembagian yang jelas antar pengguna ruas jalan. Tipe Jalan Tunjungan berubah pada era kejayaannya menjadi main street yang biasa ditemui pada area-area komersial.

Memasuki periode 1971-1990 hingga kini, tipe Jalan Tunjungan menjadi avenue dimana adanya pembagian lajur yang jelas antar pengguna jalan dan dimensi ruang pejalan kaki terlihat semakin diperlebar. Dari peta figure ground, dapat terlihat pada ruang jalan terdapat 2 (dua) tipe simpangan, yaitu simpangan 3 (tiga) sebidang dan simpangan 4 (empat) sebidang. Dari tipe simpangan ini dihasilkan varian tipe bangunan. (Lihat tabel 12) Pola ruang ini tidak berubah hingga masa kini.

Tabel 2. Diagram tipe akses di Jalan Tunjungan

Tipe jalan:
Road

Dari historical reading, diketahui adaya perubahan sistem sirkulasi kendaraan 2 (dua) arah menjadi 1 (satu) arah pada periode 1971-1990. Kepadatan kendaraan bermotor pada periode ini menghasilkan tipe pedestrian crossing bagi pejalan kaki yaitu jembatan. Tetapi jembatan tersebut tidak lagi berfungsi sejak memasuki periode >1990 (Alrianingrum 2010).

Sistem transportasi massal pada Jalan Tunjungan pada masa kejayaannya berupa trem dengan halte penumpang pada ujung Jalan
Tunjungan. Sistem ini kemudian digantikan dengan Suroboyo Bus dan halte penumpang hilang.

Sistem perparkiran pada Jalan Tunjungan tidak mengalami perubahan yang signifikan. Area parkir terletak pada beberapa muka toko dan juga pada lahan pertokoan. Yang membedakan adalah sistem perparkiran tersebut bersifat privat dari periode 1971-1990 hingga masa kini. (Lihat tabel 3) 
Tabel 3. Diagram sistem akses di Jalan Tunjungan

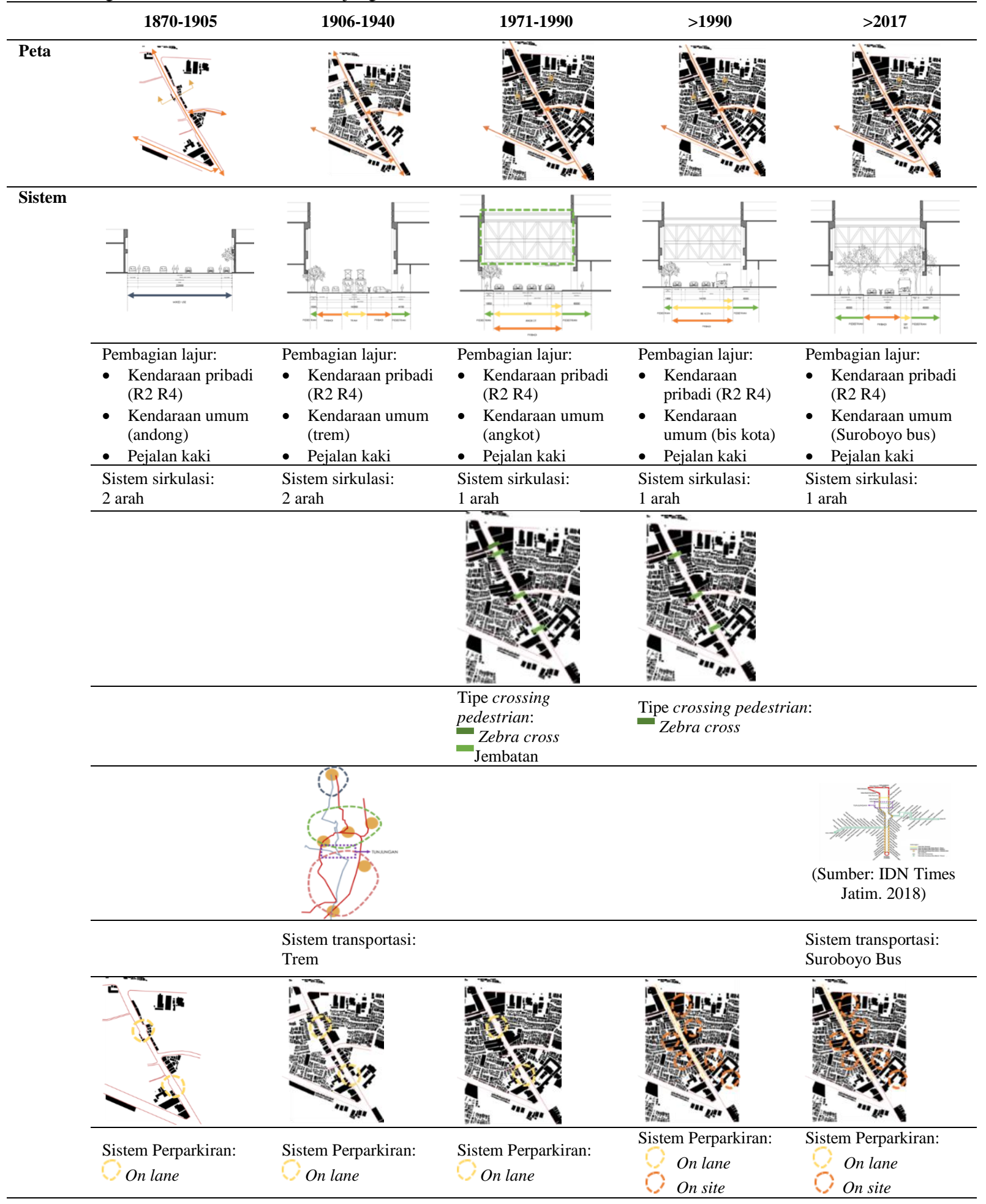




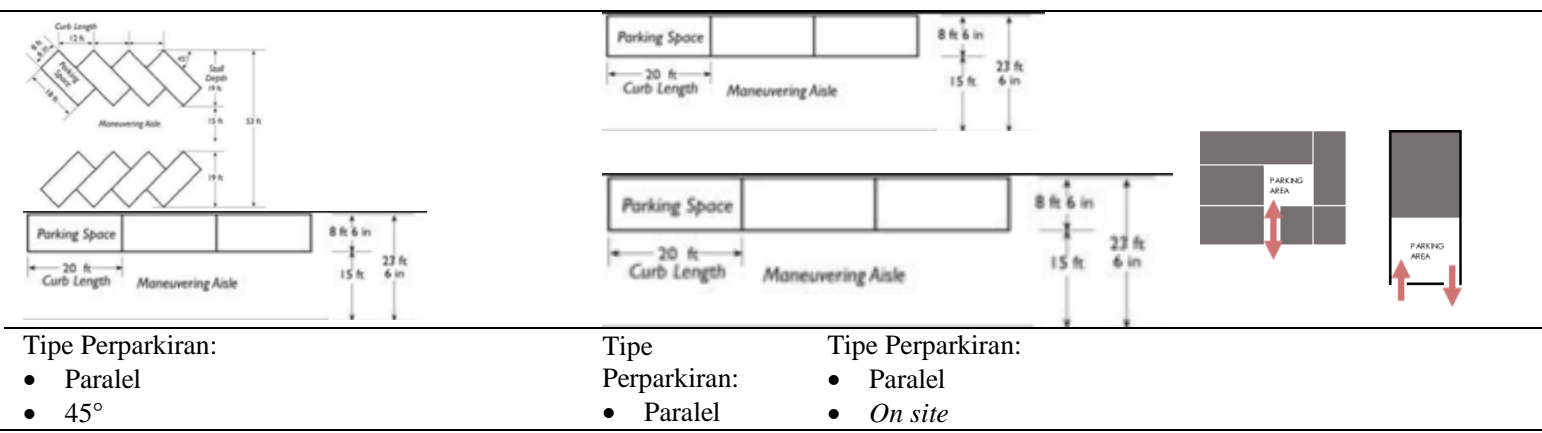

Edge

Batas pada Jalan Tunjungan berupa deretan bangunan dan tipe batas ini bertahan hingga periode $>2017$. (Lihat tabel 4)

Tabel 4. Diagram tipe batas di Jalan Tunjungan

\begin{tabular}{l} 
Peta $1906-1940 \quad 2017$ \\
\hline Tipe \\
Tipe batas: \\
Alam: Sungai dan pohon \\
Buatan: Bangunan dan jalan
\end{tabular}

Pola orientasi yang terbentuk dari tatanan bangunan yang menjadi batas pada Jalan Tunjungan adalah linier terhadap ruang Jalan.
Pola ini masih bertahan hingga periode $>2017$.

(Lihat tabel 5)

$\underline{\text { Tabel 5. Diagram pola batas di Jalan Tunjungan }}$

\begin{tabular}{llll}
\hline Pola & & & \\
\hline
\end{tabular}


Batas vertikal deretan bangunan di Jalan Tunjungan adalah sistem koridor. Karena fungsi bangunan tersebut sebagai bangunan pertokoan, maka Jalan Tunjungan dapat disebut sebagai koridor komersial. (Lihat tabel 6)

Tabel 6. Diagram sistem batas di Jalan Tunjungan

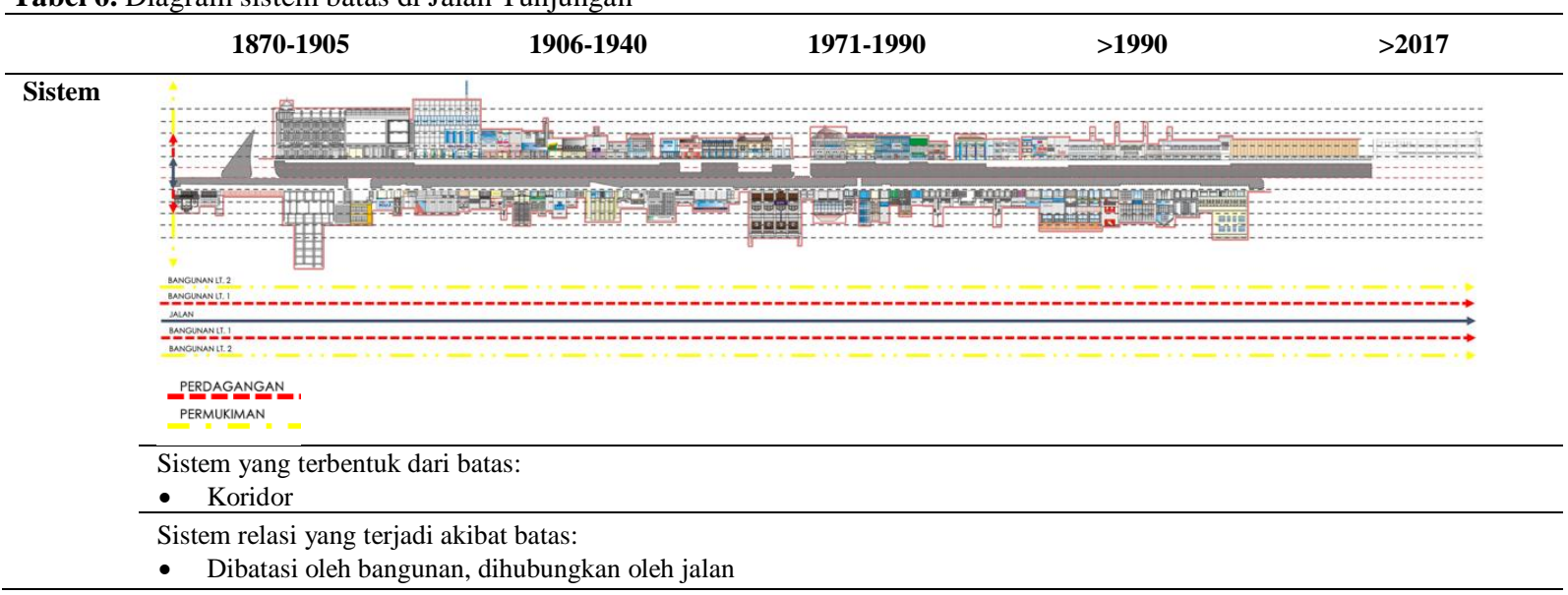

\section{Subdivision}

Dari tabel 7, terlihat bahwa subdivision pada Jalan Tunjungan terbagi menjadi 3 (tiga), yaitu: area perdagangan jasa, pemukiman, dan ruang jalan. Subdivision pada Jalan Tunjungan mengalami adaptasi mengikuti perkembangan perekonomian. Dapat dilihat bahwa pola area perdagangan jasa kini memusat di ruang jalan.

Tabel 7. Diagram pola subdivision di Jalan Tunjungan

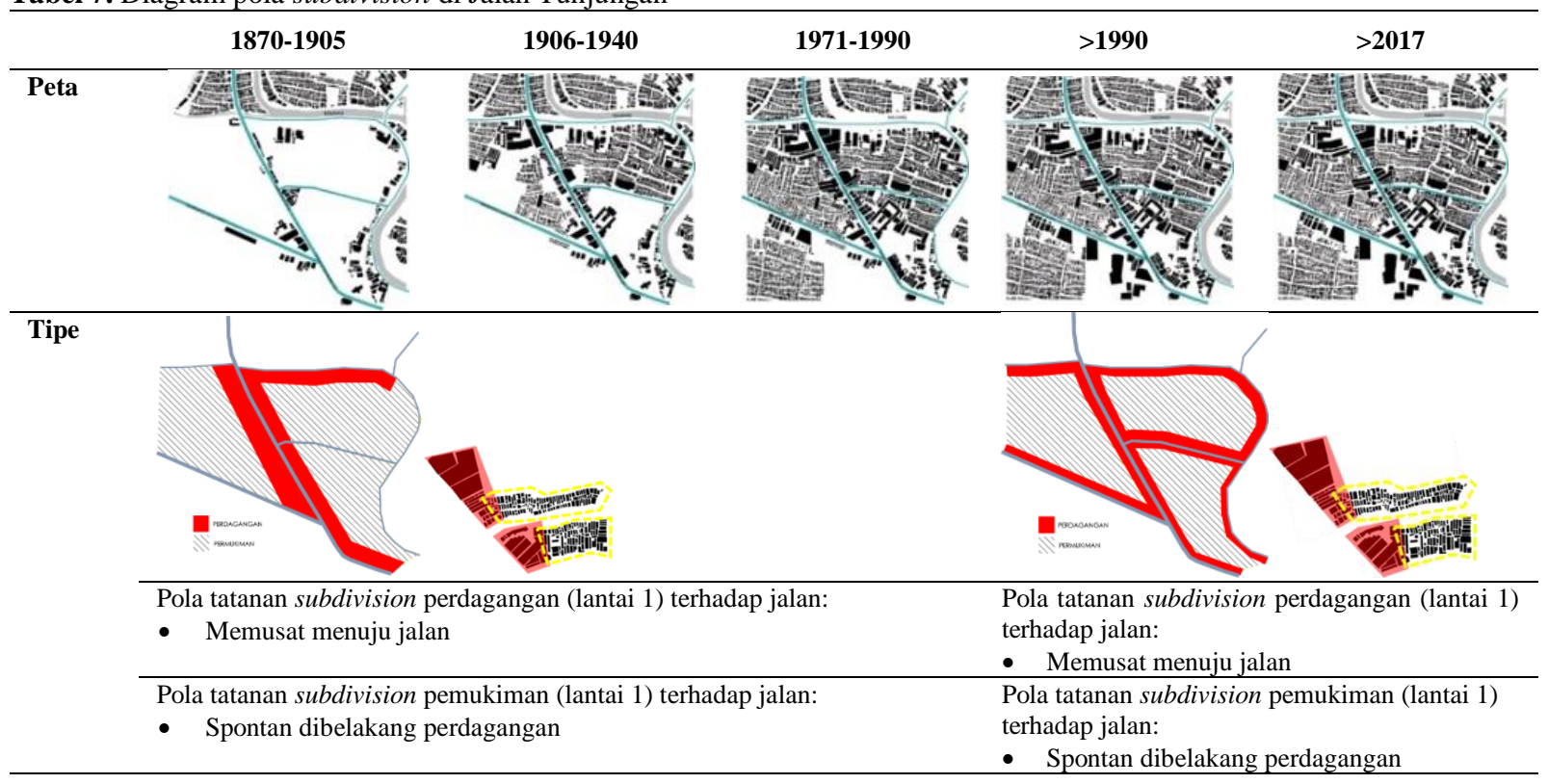

Subdivision pada Jalan Tunjungan membentuk tipologi bangunan shophouse hingga periode 1971-1990, yang kemudian mengalami transformasi menjadi bangunan komersial hingga tahun 2019. (Lihat tabel 8) 
Tabel 8. Diagram tipe subdivision di Jalan Tunjungan

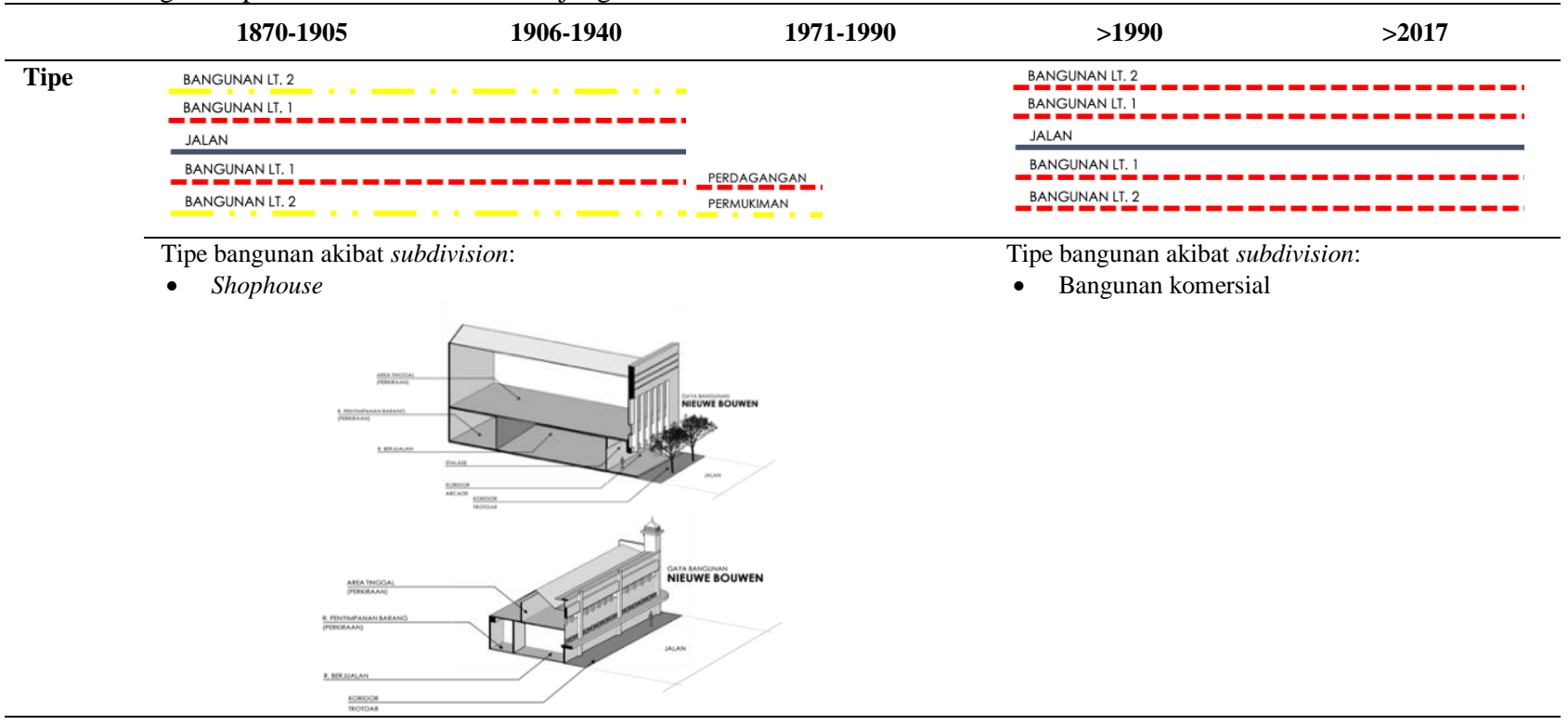

Open space

Open space yang terbentuk di Jalan Tunjungan adalah berupa void ruang jalan yang membentuk pola linier. (Lihat tabel 1)

Ruang jalan tersebut membentuk tipe jalan yang dapat dilihat pada tabel 2. Sistem relasi yang terbentuk dari pola void dan solid Jalan Tunjungan adalah sistem relasi langsung pada lantai 1 dan sistem relasi tidak langsung untuk area lantai 2. Sistem relasi ini tidak mengalami perubahan hingga masa kini. (Lihat tabel 9)

Tabel 9. Diagram sistem open space di Jalan Tunjungan

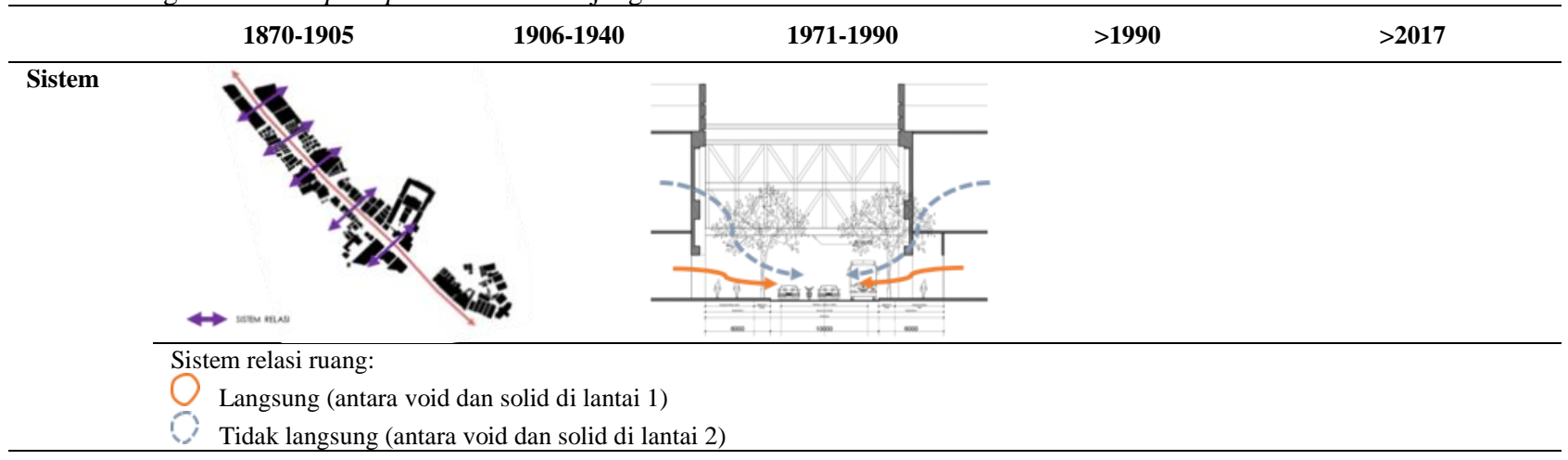

\section{Building}

Seperti yang sudah dijelaskan pada sub-bab edge, yang menjadi batas pada Jalan Tunjungan adalah deretan bangunan. Tatanan bangunan ini membentuk pola linier yang bertahan hingga masa kini. (Lihat tabel 10) 
Tabel 10. Diagram pola building di Jalan Tunjungan

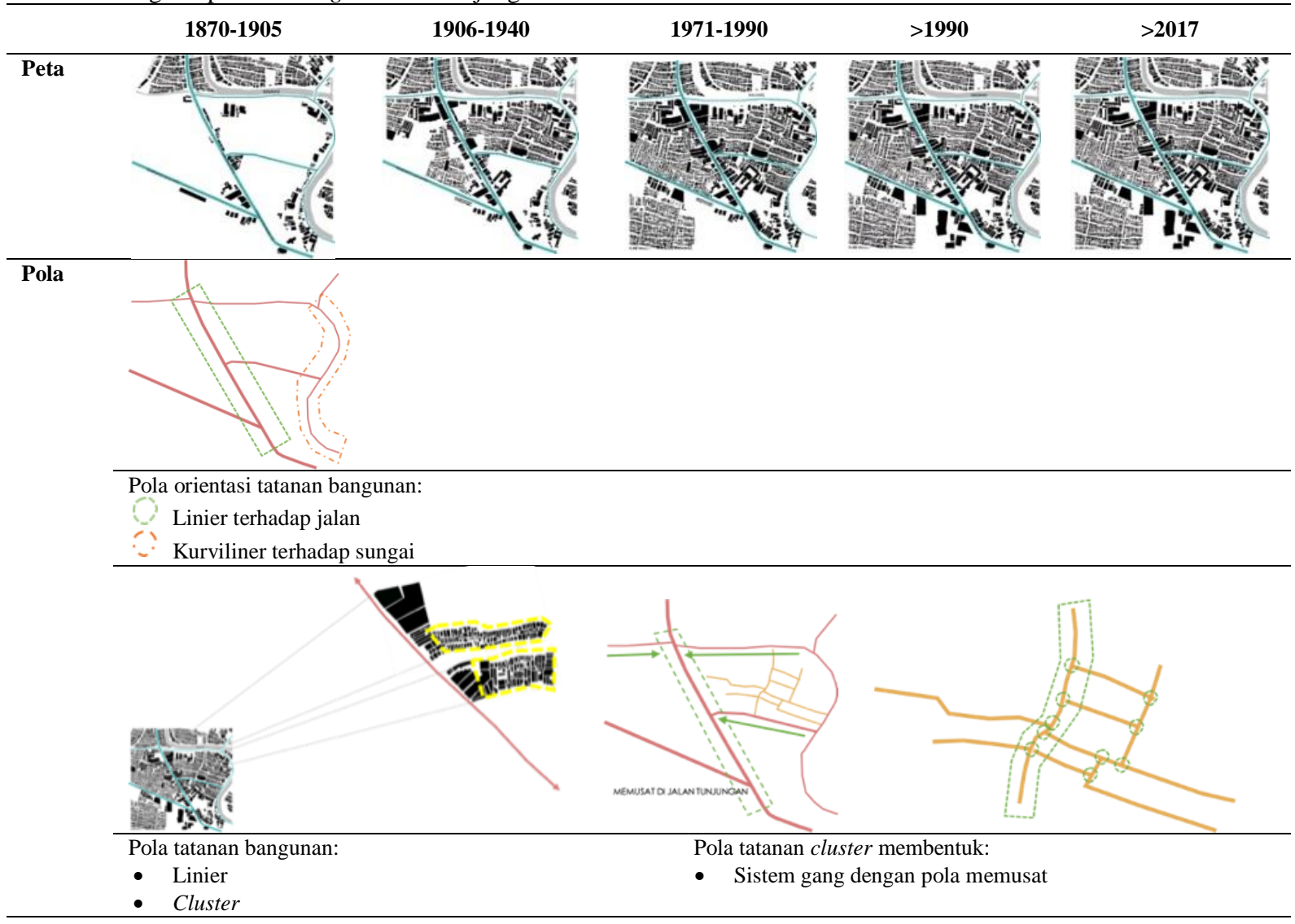

Dari tipe simpangan yang muncul pada Jalan Tunjungan, menghasilkan 2 (dua) tipe bangunan dengan tatanan rapat-renggang, yaitu corner retail dan single retail. Pada beberapa bangunan terdapat arcade untuk mengakomodasi pejalan kaki. (Lihat tabel 11 dan tabel 2)

Tabel 11. Diagram tipe building di Jalan Tunjungan

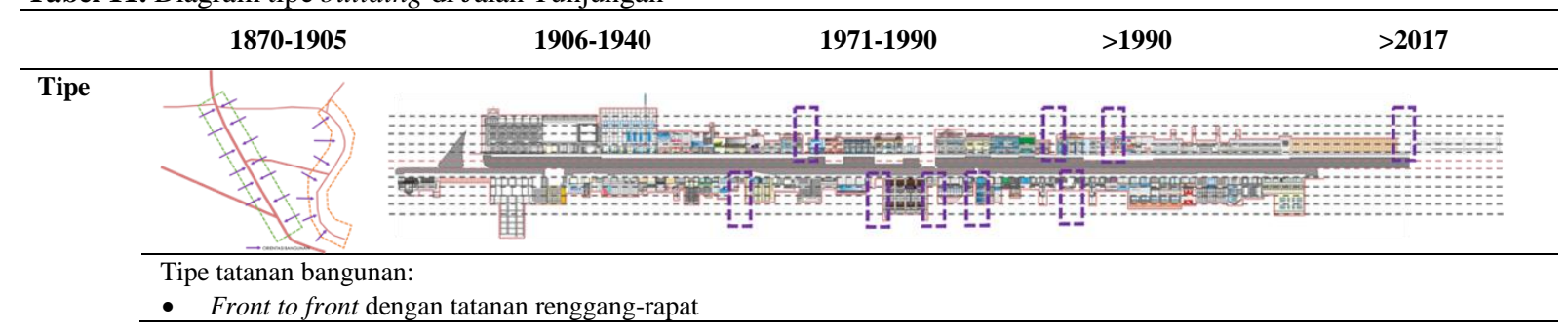




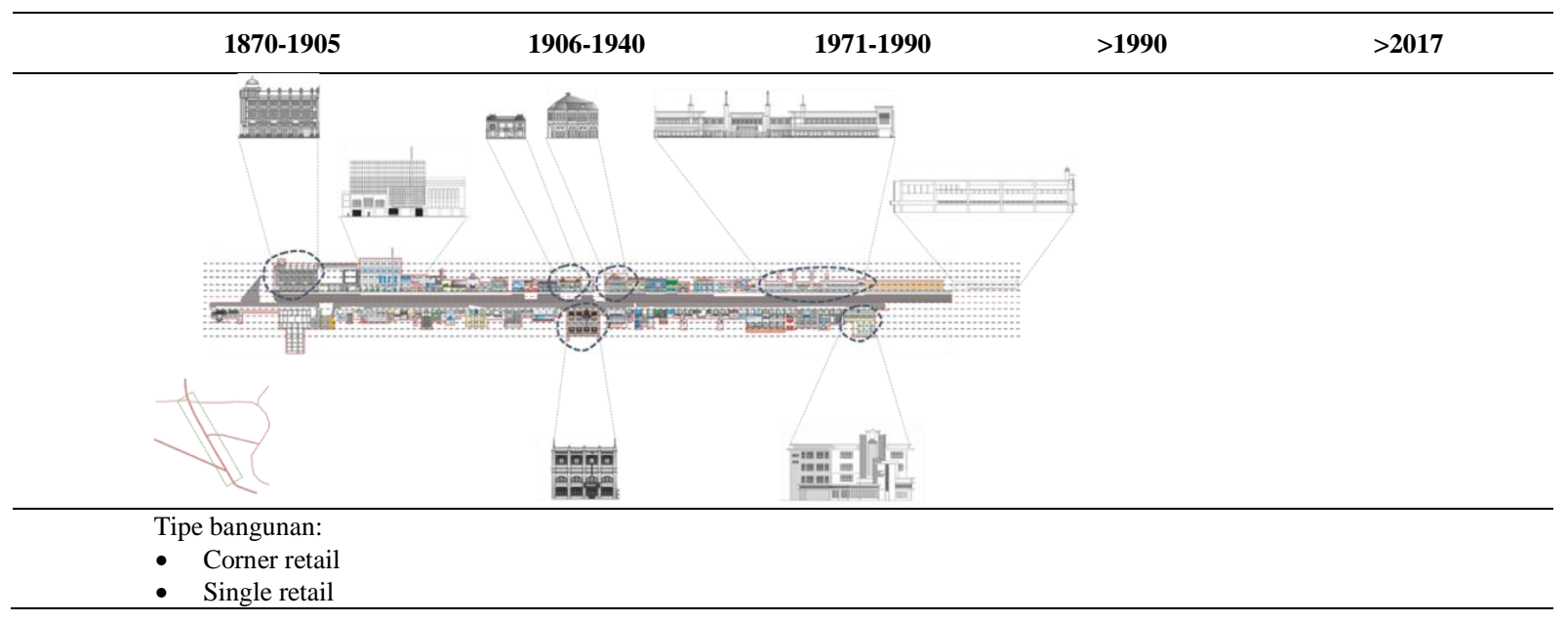

Tipe tatanan bangunan renggang-rapat menghasilkan bangunan foreground dan background. Dari bangunan tersebut terjadi sistem relasi bangunan langsung antar foreground bangunan. Selain itu, sistem bukaan bangunan adalah muka bangunan yang tidak mengalami perubahan hingga saat ini. (Lihat tabel 12)

Tabel 12. Diagram sistem building di Jalan Tunjungan

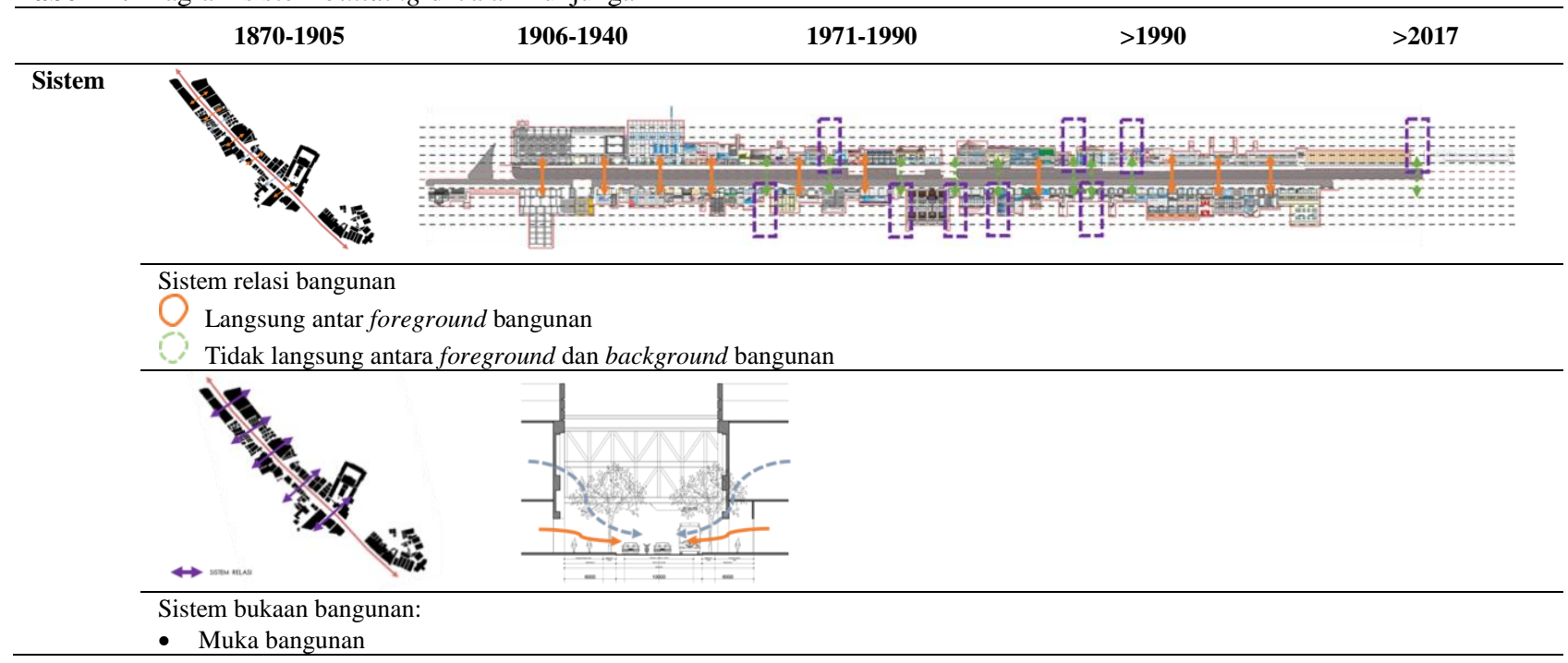

Berdasarkan studi komparasi karakteristik fisik-spasial pedestrian shopping street Jalan Tunjungan dari periode Gemeente hingga masa kini di atas, ditemukan beberapa hal berikut: (Lihat tabel 13)

Tabel 13. Hasil temuan studi

\begin{tabular}{|c|c|c|c|}
\hline & Resilien & Adaptasi & Hilang \\
\hline Access/Street & $\begin{array}{ll}\text { - } & \text { Pola liniearitas ruang } \\
& \text { jalan. } \\
\text { - } & \text { Tipe simpangan } 3 \text { (tiga) } \\
\text { sebidang dan } 4 \text { (empat). } \\
\text { - Sistem transportasi } \\
\text { massal. } \\
\text { - Sistem pedestrian. }\end{array}$ & $\begin{array}{l}\text { - Tipe jalan menjadi avenue } \\
\text { dan pembagian lajur jelas. } \\
\text { - Sistem sirkulasi menjadi } 1 \\
\text { (satu) arah. } \\
\text { - Tipe transportasi massal } \\
\text { menjadi bus. }\end{array}$ & $\begin{array}{l}\text { - Sistem transportasi massal } \\
\text { tidak menyediakan halte } \\
\text { penumpang. } \\
\text { Tipe crossing pedestrian } \\
\text { jembatan tidak lagi } \\
\text { berfungsi. }\end{array}$ \\
\hline
\end{tabular}




\begin{tabular}{|c|c|c|c|}
\hline & Resilien & Adaptasi & Hilang \\
\hline & & 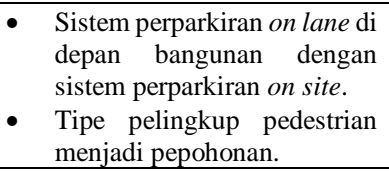 & 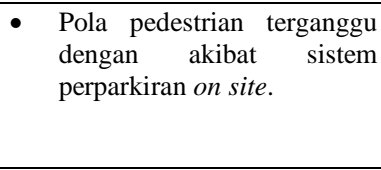 \\
\hline Edge & 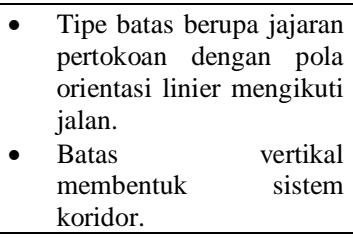 & & \\
\hline Subdivision & & 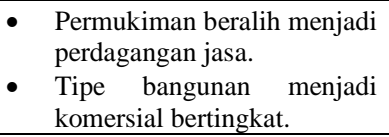 & \\
\hline Open space & $\begin{array}{l}\text { - Open space berupa ruang } \\
\text { jalan dengan pola linier. } \\
\text { - Sistem relasi langsung } \\
\text { antara solid dan void di } \\
\text { lantai dasar. }\end{array}$ & & \\
\hline Building & $\begin{array}{l}\text { - Pola liniearitas tatanan } \\
\text { dan orientasi bangunan } \\
\text { memusat di ruang jalan. } \\
\text { - Tipe bangunan corner } \\
\text { dan single retail. } \\
\text { - Sistem relasi langsung } \\
\text { antar foreground } \\
\text { bangunan. } \\
\text { - Sistem bukaan bangunan }\end{array}$ & 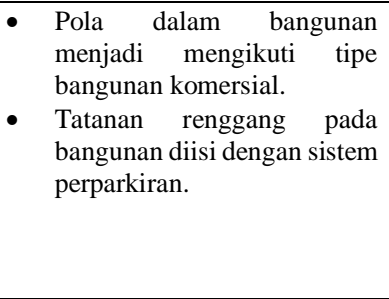 & $\begin{array}{l}\text { - Arcade pada beberapa } \\
\text { bangunan dibongkar. }\end{array}$ \\
\hline
\end{tabular}

\section{Kesimpulan}

Sejalan dengan berkembangnya Kota Surabaya, karakteristik fisik-spasial pedestrian shopping street Jalan Tunjungan juga mengalami perkembangan. Perkembangan tersebut mengakibatkan produk arsitektur di area ini ada yang bertahan, beradaptasi, dan bahkan hilang. Karakteristik fisik-spasial dapat dilihat dari pola, tipe, dan sistem yang dihasilkan dari 5 (lima) elemen urban form yang membentuk suatu kawasan. Pola, tipe, dan sistem yang membentuk karakteristik fisik-spasial pedestrian shopping street yang bertahan di Jalan Tunjungan adalah pola linearitas tatanan bangunan yang memusat di ruang jalan. Selain itu, sistem transportasi dan pedestrian juga masih bertahan. Sedangkan, karakteristik yang mengalami adaptasi adalah tipe jalan beralih menjadi avenue dengan pembagian lajur jelas. Sistem sirkulasi menjadi 1 (satu) dan penambahan sistem perparkiran on site. Selain itu, tipe bangunan beradaptasi menjadi bangunan komersial. Karakteristik yang hilang adalah arcade di beberapa bangunan dibongkar dan diubah menjadi pematang jalan, sistem transportasi massal tidak menyediakan halte penumpang, jembatan tidak lagi berfungsi, dan juga pola pedestrian terganggu akibat pola perpakiran.

Berdasarkan temuan dan kesimpulan di atas, rekomendasi yang dapat diusulkan untuk mengembalikan masa keemasan Jalan Tunjungan adalah dengan membenahi dan menghadirkan kembali pola, tipe, dan sistem yang membentuk karakteristik pedestrian shopping street Jalan Tunjungan yang hilang (lihat tabel 13), agar Jalan Tunjungan tidak lagi mengalami degradasi menjadi shopping street di era Surabaya Kota Metropolitan.

\section{Referensi}

Alexander, Christopher, Sara Ishikawa, Murray Silverstein, Max Jacobson, Ingrid FiksdahlKing, and Shlomo Angel. 1977. A Pattern Language: Towns, Buildings, Construction. New York: Oxford University Press.

Alrianingrum, Septina. 2010. 'Cagar Budaya Surabaya Kota Pahlawan Sebagai Sumber 
Belajar'. Universitas Negeri Surabaya. https://digilib.uns.ac.id/dokumen/detail/1600 6/Cagar-budaya-Surabaya-kota-pahlawansebagai-sumber-belajar-studi-kasusmahasiswa-pendidikan-sejarah-fakultas-ilmusosial-di-Universitas-Negeri-Surabaya.

Basundoro, Purnawan. 2016. 'POLITIK RAKYAT KAMPUNG DI KOTA SURABAYA AWAL ABAD KE-20'. SASDAYA: Gadjah Mada Journal of Humanities $\quad 1 \quad$ (1): 1. https://doi.org/10.22146/sasdayajournal.1702 5.

Chaer, Abdul. 2003. Linguistik Umum. Jakarta: PT Rineka Cipta.

Effendi, Zainal. 2015. 'Kembalikan Kejayaan Ikon Surabaya, Kawasan Tunjungan Tak Lagi "Bertopeng". DetikNews Berita Jawa Timur. 2015. https://news.detik.com/berita-jawatimur/d-3100092/kembalikan-kejayaan-ikonsurabaya-kawasan-tunjungan-tak-lagibertopeng.

Habraken, N. John. 2000. The Structure of the Ordinary, Form and Control in the Built Environment. Edited by Jonathan Teicher. Paperback. Cambridge: MIT Press.

Handinoto. 1996. Perkembangan Kota Dan Arsitektur Kolonial Belanda Di Surabaya, 1870-1940. Yogyakarta: Diterbitkan atas kerjasama Lembaga Penelitian dan Pengabdian kepada Masyarakat, Universitas Kristen PETRA Surabaya dan Penerbit ANDI Yogyakarta.

Hartono, Samuel, and Handinoto Handinoto. 2007. 'SURABAYA KOTA PELABUHAN (\&\#145;SURABAYA PORT CITY\&\#146;) Studi Tentang Perkembangan \&\#145;Bentuk Dan Struktur\&\#146; Sebuah Kota Pelabuhan Ditinjau Dari Perkembangan Transportasi Akibat Situasi Politik Dan Ekonomi Dari Abad 13 Sampai Awal Abad 21'. DIMENSI (Journal of Architecture and Built Environment) $\quad 35 \quad$ (1): 88-99. https://doi.org/10.9744/dimensi.35.1.88-99.

Hartshorn, Truman A. 1992. Interpreting the City: An Urban Geography. 2nd Editio. New York: John Wiley \& Sons Inc.

Hendrawan, Christianto, and Yohanes Basuki Dwisusanto. 2017. 'Onsep Active Living Dalam Perancangan Jalur Pedestrian, Studi Kasus: Jalan L. L. R. E. Martadinata (Riau),
Bandung, Jawa Barat'. ARTEKS: Jurnal Teknik Arsitektur 2 (1): 15-32. https://doi.org/10.30822/arteks.v2i1.38.

Jayadinata, Johara T. 1986. Tata Guna Tanah Dalam Perencanaan Pedesaan, Perkotaan, Dan Wilayah. Edited by 3. Bandung: ITB.

Kostof, Spiro, Greg Castillo, and RIchard Tobias. 1999. The City Assembled: The Elements of Urban Form Through History. 1st North. Boston: Bulfinch Press.

Lake, Reginaldo Christophori, Yuliana Bhara Mberu, and Avitu Diaz. 2019. 'ELEMENELEMEN PEMBENTUK SISTEM KOTALAMA KUPANG'. Jurnal Arsitektur KOMPOSISI $12 \quad$ (3): 257. https://doi.org/10.24002/jars.v12i3.2235.

Laskara, Gede Windu. 2018. 'STRATEGI IMPLEMENTASI COMPACT CITY MENUJU PENGEMBANGAN KAWASAN PERKOTAAN BERKELANJUTAN'. In INFRASTRUKTUR-BANGUNAN-

KONSTRUKSI: Berbasis Lingkungan Kepariwisataan Berkearifan Lokal. Denpasar: Fakultas Teknik Universitas Warmadewa. https://www.researchgate.net/publication/332 380047_STRATEGI_IMPLEMENTASI_CO MPACT_CITY_MENUJU_PENGEMBANG AN_KAWASAN_PERKOTAAN_BERKEL ANJUTAN.

Mutfianti, Ririn Dina. 2013. 'Mengembalikan Spirit of Place, Sebuah Upaya Mempertahankan Citra Koridor Jalan Tunjungan Surabaya'. E-Jurnal EcoTeknologi UWIKA (EJETU) I (Vol 1, No 1 (2013)): 23-32.

Perdana, Denza. 2017. 'Masa Depan Jalan Tunjungan Surabaya'. Suarasurabaya.Net. 2017.

https://www.suarasurabaya.net/kelanakota/20 17/Masa-Depan-Jalan-Tunjungan-Surabaya/.

Poerbantanoe, Benny. 1999. 'THE LOST-CITY DAN LOST-SPACE KARENA PERKEMBANGAN PENGEMBANGAN TATA-RUANG KOTA Kasus: Koridor Komersial Jalan Tunjungan, Kotamadya Surabaya'. DIMENSI TEKNIK ARSITEKTUR VOL. 27, NO. 2, DESEMBER 1999: 31 - 39.

Salura, Purnama. 2010. Arsitektur Yang Membodohkan. 1st ed. Bandung: CSS Publishing. 